\title{
DAKWAH KULTURAL MELALUI TRADISI AKKORONGTIGI (Studi pada Masyarakat Kelurahan Limbung, Kecamatan Bajeng, Kabupaten Gowa)
}

Nirwan Wahyudi $\mathbf{A R}^{1}$ dan Asmawarni ${ }^{2}$

Sekolah Tinggi Agama Islam Negeri Majene

Email: ${ }^{1}$ nirwanwahyudi.ar@ @ stainmajene.ac.id | ${ }^{2}$ asmawarni.samad@gmail.com

\begin{abstract}
Abstrak
Artikel ini bertujuan untuk mendeskripsikan pelaksanaan tradisi akkorongtigi di Kelurahan Limbung, Kecamatan Bajeng, Kabupaten Gowa, serta menginterpretasikan dakwah simbolik yang terdapat di dalam prosesinya. Penulis mengumpulkan data melalui penelusuran pustaka, observasi lapangan, dan wawancara dengan tokoh agama dan tokoh adat setempat. Akkorongtigi merupakan salah satu rangkaian tradisi pernikahan suku Makassar. Prosesinya diawali dengan appassili (mandi uap) di pagi hari, lalu pada malam hari dilaksanakan appatamma (khatam Alquran), dilanjutkan dengan acara inti yakni akkorongtigi dan ditutup dengan anynyori/annangra (pemberian sumbangan kepada keluarga calon mempelai). Setidaknya terdapat tujuh macam elemen atau bahan yang harus disiapkan pada prosesi akkorongtigi yang semuanya mengandung pesan-pesan dakwah simbolik. Dengan memahami pesan-pesan tersebut, masyarakat diharapkan melaksanakan tradisi akkorongtigi tidak sebatas seremonial belaka, namun juga bisa menghayati dan mengaktualisasikannya sehingga misi dakwah kultural melalui tradisi akkorongtigi bisa terlaksana dan efektif.
\end{abstract}

Kata Kunci: strategi dakwah, dakwah kultural, tradisi akkorongtigi.

\section{PENDAHULUAN}

Segala aspek kehidupan manusia dipermudah dengan adanya sistem digital, tak terkecuali kegiatan dakwah. Media dakwah kontemporer sangat beragam sehingga sulit untuk dibatasi pengguna dan sasarannya, misalnya penggunaan media elektronik, media cetak, dan media sosial (internet). Namun, seiring perkembangan zaman tersebut, pendekatan dakwah kultural cenderung kurang diberdayakan bahkan terabaikan dalam arti sebatas dilaksanakan sebagai ritual, tanpa penghayatan atau pemaknaan terhadap substansi pesan yang terkandung di dalamnya. 
Salah satu keberhasilan para juru dakwah terdahulu dalam menyebarkan Islam di Indonesia adalah karena kecakapannya berdakwah dengan pendekatan budaya yang mengakar pada masyarakat setempat, seperti diikhtiarkan oleh Wali Sanga. Berbagai cara ditempuh oleh Wali Sanga dalam menyebarkan ajaran Islam yang diintegrasikan dengan budaya lokal masyarakat. Sunan Kudus misalnya, menggunakan sapi (hewan suci umat Hindu) sebagai media dakwah pada masyarakat yang sebagian besar beragama Hindu. Sunan Kalijaga menciptakan perayaan sekaten (asal kata dari syahadatain [dua kalimat syahadat]) untuk memperingati maulid Nabi Muhammad saw. Pelaksanaan sekaten diakhiri dengan upacara grebeg yang disertai dengan pembacaan sirah atau riwayat hidup Rasulullah Muhammad saw., dan sedekah sekaten. Selain itu, Sunan Kalijaga juga menciptakan cerita-cerita wayang yang diselaraskan dengan cerita Mahabarata dan mengadakan pertunjukan wayang dengan ucapan dua kalimat syahadat. Contoh cerita wayang yang diciptakannya adalah cerita serat dewa ruci yang mengibaratkan usaha ke arah tarekat, hakikat hingga makrifat. Sunan Giri menciptakan kitab ilmu falak yang disesuaikan dengan alam pikiran Jawa. ${ }^{1}$

Pendekatan kultural oleh Wali Sanga dalam penyebaran Islam di tanah Jawa cenderung kental akan nilai-nilai budaya Hindu dan Budha, meskipun tentu ada ajaran-ajaran Islam yang tidak bisa dikompromikan seperti tata cara shalat dan sebagainya. Para wali tidak berusaha secara frontal dalam menghadapi masyarakat setempat, tetapi ada strategi budaya yang dikembangkan agar Islam bukan merupakan sesuatu yang asing bagi masyarakat setempat, tetapi merupakan sesuatu yang akrab karena sarana, bahasa, dan pendekatan yang dipakai merupakan hal-hal yang sudah dekat dengan mereka. Pendekatan-pendekatan yang kompromis inilah yang melahirkan banyak produk budaya dalam masyarakat, yang tentu saja mengandung unsur dakwah disamping seni dan hiburan yang dapat menyampaikan misi Islam yang rahmatan li al 'alamin.

${ }^{1}$ Murodi, Sejarah Kebudayaan Islam (Semarang: PT Karya Toha Putra, [t.th.]), h. 206. 
Pendekatan serupa juga diterapkan oleh para pengemban misi dakwah Islam di Sulawesi Selatan, termasuk dapat diamati melalui tradisi-tradisi pernikahan yang di dalamnya terdapat upaya untuk menanamkan nilai-nilai atau pesan-pesan Islam, baik secara eksplisit maupun implisit. Salah satu tradisi pernikahan yang dikenal luas oleh masyarakat suku Makassar adalah akkorongtigi yang hingga kini masih dipegangteguh dan dilestarikan.

Penulis tertarik menelaah prosesi dari tradisi akkorongtigi untuk menginterpretasikan pesan-pesan simbolik yang terkadung di dalamnya. Dengan memahami pesan-pesan tersebut, masyarakat diharapkan melaksanakan tradisi akkorongtigi tidak sebatas seremonial belaka, namun juga bisa menghayati dan mengaktualisasikannya sehingga misi dakwah kultural melalui tradisi akkorongtigi bisa terlaksana dan efektif.

\section{PEMBAHASAN}

\section{Pendekatan Kultural dalam Dakwah}

Penentuan pendekatan dakwah didasarkan atas kondisi objektif dari sasaran dakwah dan suasana yang melingkupinya. Dalam masyarakat yang sedang terhimpit ekonomi misalnya, tentu dakwah dengan pendekatan ekonomi akan lebih tepat guna, dari pada pendekatan psikologis semata. Demikian halnya pendekatan ekonomi tidak akan banyak manfaatnya jika dihadapkan pada sasaran dakwah yang sedang mengalami gangguan mental akibat dari ketidakharmonisan dalam hubungan keluarga. Mereka akan lebih tepat didekati secara psikologis. Menurut Alwi Shihab yang dikutip Rosyidi, dakwah yang efektif membutuhkan pendekatan yang berubahubah dan metodologi yang sesuai dengan sejarah dan komunitas sasaran. ${ }^{2}$

Secara teoretis, ada beberapa pendekatan (approach) yang bisa dilakukan dalam dakwah, seperti pendekatan budaya, pendekatan pendidikan ekonomi, dan pendidikan psikologis. Ali Azis membagi pendekatan ini dalam dua bentuk: Pertama, pendekatan sosial (social aproach). Pendekatan ini didasarkan atas pandangan bahwa penerima pesan atau sasaran dakwah adalah manusia yang memiliki naluri sosial,

\footnotetext{
${ }^{2}$ Rosyidi, Dakwah Sufistik Kang Jalal (Jakarta: Paramidana, 2004), h.50.
} 
selalu ingin berinteraksi dan memiliki ketergantungan dengan orang lain. Interaksi sosialini dimaksudkan untuk memenuhi hajat hidup mereka yang tidak akan mungkin bisa dipenuhi oleh orang perorang secara individual. interaksi ini banyak macamnya, meliputi semua aspek kehidupan, mulai dari politik, ekonomi, budaya, pendidikan, dan lain-lain.

Kedua, pendekatan psikologis (psychological approach). Pendekatan ini meliputi dua aspek pandangan: 1) citra pandang dakwah terhadap manusia sebagai makhluk yang memiliki kelebihan disbanding dengan makhluk lain. Oleh karena itu mereka harus dihadapi dengan persuasif, hikmah dan kasih sayang; 2) realitas pandang dakwah terhadap sasaran dakwah yang disamping memiliki beberapa kelebihan, ia juga memiliki beberapa kekurangan dan keterbatasan. Ia seringkali gagal dalam melakukan komunikasi dengan keluarga, teman, pimpinan, masyarakat, sehingga ia mengalami gangguan kejiwaan. Oleh karena itu dakwah harus memandang mitra dakwahnya sebagai manusia dengan segala problematikanya. Pendekatan psikologis ini perlu terutama bagi mereka yang memerlukan pemecahan masalah rohani, baik dengan bimbingan penyuluhan maupun dengan metode-metode yang lain. ${ }^{3}$

Dalam Kamus Besar Bahasa Indonesia (KBBI), kultural berarti berhubungan dengan kebudayaan. Maka dakwah kultural secara etimologi dapat diartikan sebagai kegiatan dakwah yang dilakukan melalui pendekatan kebudayaan.Pendekatan kultural mendahulukan kultur atau tradisi yang dijunjung tinggi dan ada ditengah masyarakat untuk memanfaatkan seoptimal mungkin dalam rangka mencapai tujuan dakwah.

Menurut Syamsul Hidayat seperti dikutip Abdul Basit, dakwah kultural merupakan kegiatan dakwah yang memerhatikan potensi dan kecenderungan manusia sebagai makhluk berbudaya, guna menghasilkan budaya alternatif yang islami, yakni berkebudayaan dan berperadaban yang dijiwai dengan pemahaman, penghayatan dan pengalaman ajaran Islam yang bersumber dari ajaran Islam dan al-Sunnah serta

${ }^{3}$ Moh. Ali Aziz, Ilmu Dakwah (Cet. III; Jakata: Kencana, 2012), h. 347. 
melepaskan diri dari budaya yang dijiwai oleh kemusyrikan, takhayul, bid'ah, dan khurafat. $^{4}$

Secara substansial, misi dakwah kultural adalah upaya melakukan dinamisasi dan purifikasi. Dinamisasi bermakna sebagai kreasi budaya yang memiliki kecenderungan untuk selalu berkembang dan berubah ke arah yang lebih baik dan Islami. Purifikasi diartikan sebagai usaha pemurnian nilai-nilai dalam budaya dengan mencerminkan nilai-nilai tauhid.

Dakwah kultural tidak menganggap kekuatan politik sebagai satu-satunya alat perjuangan dakwah. Dakwah kultural menjelaskan, bahwa dakwah itu sejatinya adalah membawa masyarakat agar mengenal kebaikan universal, kebaikan yang diakui oleh semua manusia tanpa mengenal batas ruang dan waktu. Dakwah kultural hadir untuk mengukuhkan kearifan-kearifan lokal yang ada pada suatu pola budaya tertentu dengan cara memisahkannya dari unsur-unsur yang bertentangan dengan nilai-nilai Islam. ${ }^{5}$

Dakwah kultural memiliki peran yang sangat penting dalam kelanjutan misi Islam di Bumi ini. Suatu peran yang tak diwarisi Islam politik atau struktural yang hanya mengejar kekuasaan yang instan. Oleh karena itu, dakwah kultular harus tetap ada hingga akhir zaman. Para juru dakwah yang bijak harus memiliki informasi yang lengkap dari masyarakat tertentu, sebagai modal dasar dalam mengkomunikasikan pesan-pesan Islam. Seringkali kurangnya atau tidak memadahinya informasi tentang penerima dakwah membuat kerja dakwah menjadi tidak memuaskan. ${ }^{6}$

Menurut Said Aqil Siradj, jika dilihat secara historis, dakwah kultural sudah ada sejak zaman Muawiyah yang dipelopori oleh Hasan Bashri yaitu dengan mendirikan forum kajian yang nantinya melahirkan para ilmuwan dari berbagai

\footnotetext{
${ }^{4}$ Abdul Basit, FIlsafat Dakwah (Cet. I; Jakarta: Rajawali Pers, 2013), h. 170.

${ }^{5}$ Ilyas Ismail, Filsafat Dakwah: Rekayasa Membangun Agama dan Peradaban Islam (Jakarta: Kencana, 2011), h.. 249

${ }^{6}$ Rosyidi, Dakwah Sufistik Kang Jalal, h. 52.
} 
disiplin ilmu, hingga kemudian diteruskan oleh para Wali Sanga, KH. Hasyim Asy'ari, KH. Ahmad Dahlan dan lain sebagainya. ${ }^{7}$

KH. Ahmad Dahlan termasuk sosok mubalig yang dalam menyampaikan dahwahnya dengan menggunakan metode dakwah kultural pada sekitar tahun 1912an. Karena beliau menyadari bahwa metode dakwah yang tepat saat itu hanyalah metode dakwah kultural. ${ }^{8}$ Namun karena kehati-hatiannya dengan masalah aqidah, walaupun menggunakan metode dakwah kultural, tetap nilai-nilai Islam tidak terlukai oleh model dakwah yang dilakukan. Justru sebaliknya dengan dakwah itulah, maka beliau dapat membersihkan nilai-nilai ajaran Islam dari pengaruh budaya kultural setempat.

Agama Islam hadir bukan di alam yang hampa, melainkan dalam ruang dan waktu dimana manusia berada didalamnya. Sementara, manusia sebagai makhluk yang memiliki pola pikir dan pola sikap tentu akan merespon kehadiran islam sesuai dengan kebutuhan manusia itu sendiri. Jika kehadiran Islam tidak merespon kebutuhan manusia dan tidak memperdulikan pola pikir dan pola sikap manusia, maka kehadiran Islam hanya sebagai ritus belaka. Sebaliknya, respon manusia terhadap Islam hanya sebatas pemenuhan kebutuhan manusia tanpa memperdulikan kesucian dari ajaran Islam, maka kesakralan ajaran Islam akan tercoreng oleh manusia. Pada konteks demikian, dakwah kultural menjadi penting kehadirannya untuk memberikan penjelasan dan pemahaman terkait dengan korelasi antara Islam dan manusia.

Dakwah kultural dapat dipahami sebagai sebuah strategi perubahan sosial bertahap sesuai dengan kondisi empirik yang diarahkan kepada pengembangan kehidupan Islami yang bertumpu kepada pemurnian pemahaman dan pengalaman ajaran Islam dengan menghidupkan ijtihad dan tajdid. Dengan demikian, dakwah model ini menggunakan pendekatan kepada budaya lokal, kultur masyarakat, serta

\footnotetext{
${ }^{7}$ Said Aqil Siradj, Islam Kebangsaan Fiqh Demokratik Kaum Santri (Cet. I; Jakarta : Pustaka Ciganjur, 1999), h. 35.

${ }^{8}$ Forum Silaturrahmi Keluarga Besar Alumni FIAD UNMUH Surabaya, "Dakwah Kultural”, http://alumnifiad.youneed.us/t43-dakwah-kultural (20 Maret 2015).
} 
nilai-nilai yang telah mapan, tetapi tetap mempunyai semangat kepada ijtihad dan tajdid dalam rangka purifikasi.

Secara teknis, dakwah kultural dapat juga dimaknai sebagai dialog antara idealitas nilai-nilai agama dan realitas kultur masyarakat yang multikultural. Interaksi dengan pluralitas budaya tersebut, terlebih khusus seni budaya dan komunitasnya telah melahirkan sejumlah ketegangan, baik yang berupa kreatif maupun destruktif (menggambarkan). Ketegangan ini bersumber pasa realitas historis-sosiologis, bahwa banyaknya kebudayaan dan seni budaya pada khususnya yang dikembangkan berasal dari ritual-ritual keagamaan sebelum kedatangan Islam. Sehingga banyak di antaranya mengandung nilai-niali atau norma-norma yang bertentangan dengan akidah Islam.

Dakwah kultural dalam tataran ini menemukan relevansinya dengan realitas sosial, yakni dalam rangka mengubah kebudayaan yang bertentangan dengan akidah Islam tanpa perlu menimbulkan resistensi terutama dari para pengusung kebudayaan tersebut. Oleh karena itu, dakwah kultural dapat menjadi strategi dakwah yang berperan untuk memediasi ketegangan yang sering terjadi antara doktrin agama dengan doktrin budaya setempat.

Ini mungkin yang dimaksud dengan pengertian gagasan pemurnian dan kebangkitan Islam dan paradigma ijtihad, bahwa dakwah kultural merupakan jawaban atas persoalan peran sejarah dan peradaban dalam alam modernitas. Pemurnian atau purifikasi ajaran Islam dari budaya-budaya yang bertentangan dengan akidah justru memerlukan pendekatan budaya. Perlu sebuah penyikapan yang akomodatif dengan menghilangkan sifat resistensi yang represif terhadap pluralitas budaya di mana hal tersebut hanya ditemukan di dalam konsep dakwah kultural.

Selain itu, dakwah kultural juga dapat menjadi semacam tenda besar bagi bangsa kerena mempertimbangkan dan menyantuni realitas masyarakat Indonesia yang plural dan multikultural dalam wacana dan gerakan dakwah. Tenda besar bagi umat Islam karena mengusung semangat kebersamaan antar golongan di kalangan internal dan eksternal umat menuju tercapainya masyarakat madani. Setiap kebijakan dakwah yang berwawasan kultural dan multikultural diharapkan mampu mendorong 
lahirnya sikap apresiatif, toleransi, prinsip kesetaraan antar budaya, kesetaraan gender, kesetaraan antar berbagai kelompok etnik, kesetaraan bahasa, agama dan sebagainya.

Tradisi Akkorongtigi pada Masyarakat Kelurahan Limbung, Kecamatan Bajeng, Kabupaten Gowa

Ada ungkapan di kalangan suku Makassar sebagai sindiran bagi orang yang belum malaksanakan pernikahan: "Tenapa na ganna se'rea tau punna tenapa na situtu ulunna siagan salangganna". Dalam bahasa Indonesia: "Belum menjadi manusia sempurna seseorang apabila kepalanya belum berhubungan dengan bahunya". Makna dari ungkapan tersebut adalah bahwa seseorang baru bisa dikatakan sempurna sebagai manusia bila ia sudah menikah. Ungkapan lain yang lebih populer adalah: "Iapa nakkulle abunting taua punna nakullemo nainroi pallua pintuju siallo sipattang (Seorang laki-laki baru bisa menikah apabila mampu mengelilingi dapur tujuh kali sehari semalam)". Ungkapan tersebut mengandung makna bahwa tanggung jawab sebagai suami atau istri tidaklah mudah sehingga jangan mencoba berkeluarga bila belum memiliki kemampuan secara psikologis, finansial, maupun kemampuan dalam hal pendidikan dan keterampilan sebagai bekal dalam mengarungi bahtera rumah tangga kelak.

Sebagian besar masyarakat Kelurahan Limbung Kecamatan Bajeng Kabupaten Gowa memandang bahwa pernikahan bukan sekedar menyatukan dua mempelai dalam hubungan suami istri, tetapi pernikahan merupakan suatu upacara yang bertujuan untuk menyatukan dua keluarga besar yang telah terjalin sebelumnya menjadi semakin erat atau dalam istilah orang masyarakat Kelurahan Limbung disebut nipamani bellayya (mendekatkan yang jauh). Oleh karena itu, pernikahan di kalangan masyarakat Kelurahan Limbung umumnya berlangsung antarkeluarga dekat, terutama di kalangan masyarakat biasa, karena mereka sudah saling memahami sebelumnya.

Tradisi akkorongtigi hingga kini masih tetap dipelihara secara turun temurun oleh masyarakat suku Makassar, khususnya masyarakat Kelurahan Limbung, Kecamatan Bajeng, Kabupaten Gowa. Istilah akkorongtigi diambil dari nama 
tumbuhan, yakni inai yang merupakan unsur utama dalam prosesi akkorongtigi. Keseluruhan rangkaian akkorongtigi memiliki makna yang memuat pesan-pesan dakwah. Secara nama saja, akkorongtigi bermakna bersuci yang merupakan salah satu ajaran yang ditekankan di dalam Islam, sebagaimana firman Allah swt. Q.S. Al Baqarah/2:222:

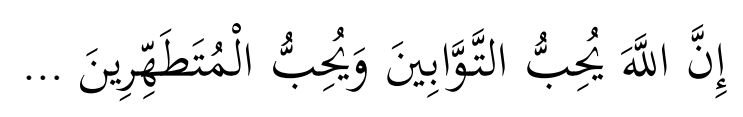

Terjemahnya:

...Sesungguhnya Allah menyukai orang-orang yang bertaubat dan menyukai orang-orang yang mensucikan diri. ${ }^{9}$

Tradisi akkorongtigi dilaksanakan satu malam sebelum prosesi akad nikah yang dimaksudkan sebagai malam mensucikan diri sebelum kepelaminan. Berikut ini uraian proses-proses yang dilalui calon mempelai sebelum, sementara, dan setelah pelaksanaan tradisi akkorongtigi.

\section{Appassili}

Sebelum melaksanakan tradisi akkorongtigi, masyarakat Kelurahan Limbung Kecamatan Bajeng Kabupaten Gowa terlebih dahulu melaksanakan tradisi appassili. Apassili atau mandi uap merupakan rangkaian tradisi dari akkorongtigi yang dimaksudkan untuk menghilangkan kotoran jasmani calon mempelai, yang dalam bahasa Makassar disebutkan oleh Ismail Daeng Ngila dengan: "Appasili iami antu nipallaisengngi ra'masa'na anjo niaka ribatang kalenna calong buntinga."10

Sebelum acara ini dilakukan, keluarga calon mempelai wanita membuatkan tempat khusus berupa gubuk siraman yang telah ditata sedemikian rupa di depan rumah atau pada tempat yang telah disepakati bersama oleh anggota keluarga. Rangkaian dari upacara ini terdiri atas: $a^{\prime} b u b u$ (mencukur rambut halus pengantin), dan appakanre bunting (menghidangkan makanan kepada tamu).

\footnotetext{
${ }^{9}$ Kementerian Agama RI, Alquran dan terjemahnya, h. 27.

${ }^{10}$ Ismail Daeng Ngila, Tokoh Agama dan Tokoh Tradisi Kelurahan Limbung Gowa, Wawancara, Bontobila, 15 Maret 2015.
} 


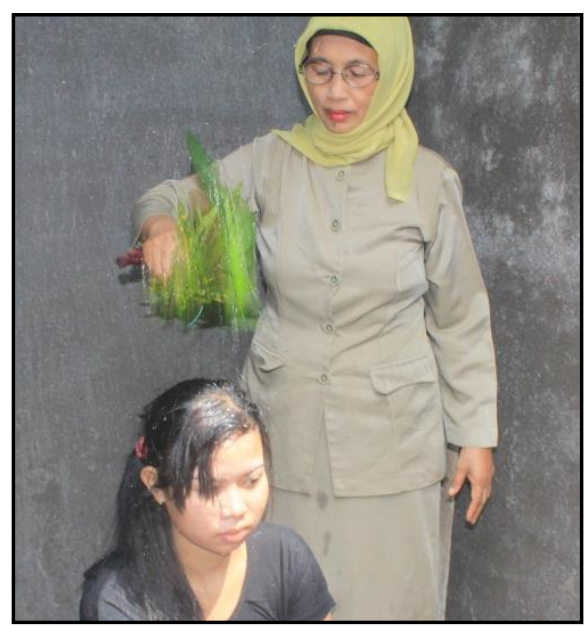

(Prosesi appassili)

\section{Appatamma}

Appatamma atau prosesi khatam Alquran yang dipimpin atau dipandu oleh guru mengaji atau orang tua calon mempelai jika bacaan Alqurannya juga sudah tamat, minimal bacaannya fasih. Namun, pada umumnya imam kampung setempatlah yang ditunjuk untuk mengambil alih tugas tersebut. Calon pengantin menggenakan busana pengantin Makassar, duduk berhadapan dengan pemandu. Posisi Alquran bertumpu di atas bantal yang membatasi posisi calon pengantin dengan pemandu.

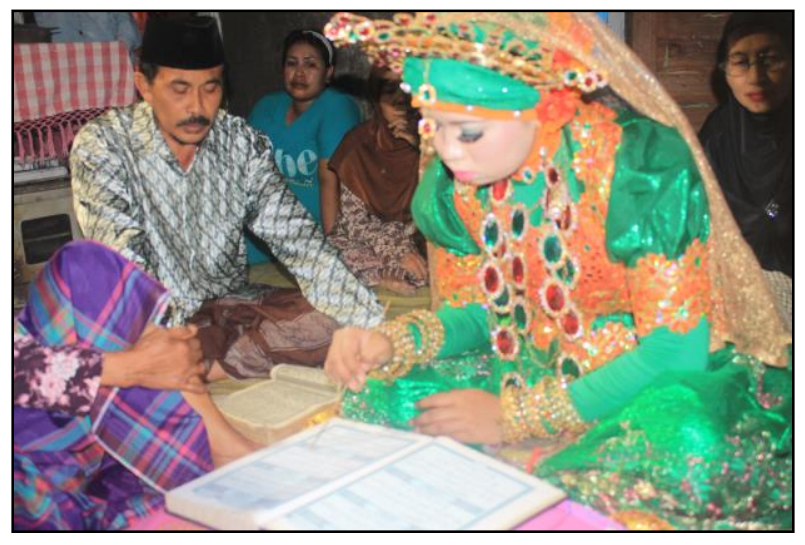

(Prosesi appatamma) 


\section{Akkorongtigi}

Setelah appatamma dilaksanakan, dilanjutkan dengan tradisi akkorongtigi, dimana dalam pelaksanaan ini calon pengantin duduk menghadap kiblat dengan tangan diatas bantal yang dialasi dengan daun pucuk pisang, kemudian salah seorang tokoh agama duduk berhadapan dengan calon pengantin. Prosesi akkorongtigi dapat dideskripsikan melalui uraian berikut:

1) Imam mengambil daun korongtigi (daun inai) dan mengolesi seluruh jari-jari calon mempelai mulai dari kanan ke kiri, serta telapak tangan kanan dan kiri.

2) Mengambil lilin dan mengangkatnya ke bagian muka dengan gerakan satu arah membentuk lingkaran.

3) Mengambil bente' (jagung meletus) kemudian di tiup ke mulut dan diberikan doa selanjutnya di bagikan pada telapak tangan kanan dan kiri.

4) Kemudian mengambil beras dan dilakukan seperti halnya dalam proses ketiga.

5) Memanjatkan doa untuk calon pengantin.

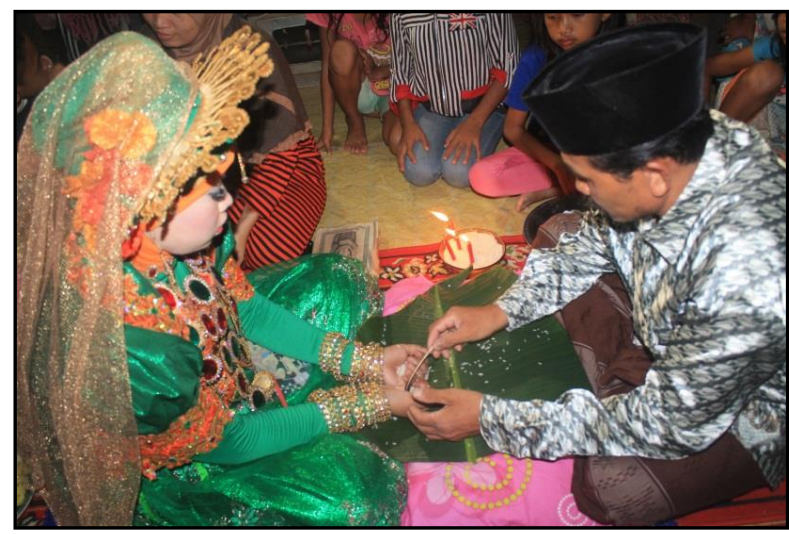

(Prosesi akkorongtigi)

\section{Anynyori/Annangra}

Anynyori atau disebut juga annangra adalah prosesi di mana para tamu memberikan sumbangan (angpau) kepada yang punya hajat atau keluarga calon mempelai. Jumlah sumbangan mulai dari puluhan ribu, ratusan ribu, bahkan sampai jutaan rupiah. Semua sumbangan itu dicatat oleh panitia yang akan diserahkan kepada tuan rumah. 


\section{Pesan Dakwah Simbolik dalam Tradisi Akkorongtigi}

Pesan dakwah pada tradisi akkorongtigi bisa ditelaah melalui dua aspek, yakni: pertama, pesan dakwah pada tata cara atau prosesi akkorontigi; dan kedua, pesan dakwah yang terdapat pada elemen atau bahan-bahan yang digunakan. Penulis menginterpretasikan pesan-pesan tersebut berdasarkan wawancara dengan tokoh agama dan tokoh adat Keluarahan Limbung Kecamatan Bajeng Kabupaten Gowa.

Prosesi akkorongtigi dilakukan dengan mengoleskan daun inai pada bagianbagian tangan calon pengantin secara bergantian sambil mendoakan. Uniknya, terdapat doa pada setiap bagian-bagian yang diolesi tersebut, antara lain:

1. Pada ibu jari diolesi dengan harapan semoga bersifat keibuan bagi perempuan dan bersifat kebapakan bagi laki-laki.

2. Diolesi pada jari telunjuk dengan harapan agar teguh pada syahadatnya (syahadatain).

3. Diolesi pada jari tengah dimaksudkan semoga tindakan dan pengambilan keputusannya arif bijaksana.

4. Pada jari manis dengan harapan semoga dikaruniai rezeki berkah yang melimpah.

5. Sedangkan pada jari kelingking dengan harapan semoga tetap hidup bersahaja, tidak berlebih-lebihan, hingga takabur dan sombong.

6. Pada telapak tangan dengan harapan agar dapat memegang amanah dengan baik sebagai suami/ayah dan istri/ibu.

Sementara pesan dakwah yang terdapat pada elemen atau bahan-bahan yang digunakan dalam tradisi akkorongtigi penulis uraikan sebagai berikut:

1. Daun korongtigi atau inai, merupakan bahan utama dalam tradisi akkorongtigi, yang dipahami masyarakat setempat sebagai simbol kesucian. Daun korongtigi yang telah ditumbuk, diletakkan di atas telapak tangan calon mempelai oleh orangorang yang memiliki kedudukan dan kehidupan sosial yang baik, telah berumah tangga dengan langgeng dan bahagia, baik dari pihak keluarga, tokoh agama, dan tokoh adat setempat. Pesan dakwah yang dapat diambil dari penggunaan korongtigi ini adalah bahwa selain calon mempelai memasuki hubungan rumah 
tangga dalam keadaan bersih secara lahir dan batin, calon mempelai juga didoakan agar juga dapat hidup langgeng, bahagia, serta memiliki kehidupan yang baik.

2. Tai bani atau lilin, ditempatkan di atas beras bersama dengan kelapa dan gula. Pesan dakwah yang dapat diambil dari penggunaan lilin ini yakni: pertama, agar calon mempelai nantinya dapat menjadi panutan atau teladan yang baik dan menjadi sosok yang dibutuhkan karena senantiasa memberi manfaat di tengahtengah kehidupan bermasyarakat sebagaimana sifat lilin yang dapat menjadi penerang bagi manusia, yang dapat mengubah gelap menjadi terang; kedua, pesan kepada calon mempelai agar menjalani hubungan rumah tangga dengan didasari sifat saling setia dan sabar dalam menjalani berbagai rintangan hingga ajal menjemput sebagaimana sifat lilin yang setia memberikan sinarnya hingga pupus; dan ketiga, pesan kepada calon mempelai agar dalam berumah tangga nanti rela berkorban satu sama lain, sesuai dengan sifat lilin yang rela sumbu dan tubuhnya meleleh demi menerangi manusia.

3. Beras, merupakan makanan pokok orang Indonesia pada umumnya, dan secara khusus masyarakat Kelurahan Limbung Kecamatan Bajeng Kabupaten Gowa. Beras berasal dari proses pengolahan padi. Mulai dari pembibitan, kemudian melalui proses panjang berikutnya, maka jadilah padi yang siap dipanen. Setelah dipanen dan diproses jadi beras, maka beras pun siap dimasak menjadi nasi. Pesan yang dapat dipetik dari penggunaan beras dalam proses tradisi akkorongtigi ini adalah bahwa dalam mengarungi kehidupan nantinya, calon mempelai harus memiliki sifat beras, yakni dalam menggapai sesuatu harus diawali dari usaha yang sunguh-sungguh, bekerja dengan gigih, dan sabar dalam melalui setiap proses.

4. Bente', terbuat dari jagung yang digoreng atau disangrai. Pada pelaksanaan tradisi akkorongtigi, bente' dihamburkan beriringan dengan beras kepada calon mempelai. Pesan dakwah yang dapat dipetik adalah diharapkan calon mempelai senantiasa memiliki sifat mandiri dalam membina rumah tangganya dan suka berbagi sehingga rezekinya bisa lancar seperti pembuatan bente tersebut yang 
cepat memekar saat digoreng. Dalam bahasa Makassar diistilahkan "tettereki aklappo dallena nana pakbagebageang mange ritaua".

5. Pa'lungang atau bantal, terbuat dari kapas dan kapuk, suatu perlambang kemakmuran. Batal sebagai pengalas kepala, di mana kepala adalah bagian paling mulia bagi manusia. Dengan demikian pesan dakwah yang dapat dipetik dari penggunaan pa'lungang atau bantal adalah agar calon mempelai senantiasa menjaga kehormatan, kemulian, atau harkat keluarganya dan saling hormat menghormati antar keluarga kedua mempelai.

6. Cappa unti atau daun pucuk pisang, diletakkan di atas bantal, di mana di atas daun pucuk pisang inilah nantinya kedua telapan tangan calon mempelai diletakkan. Melambangkan kehidupan sambung menyambung (berkesinambungan) atau dalam bahasa Makassar disebut "teako ammari usaha sa'genna nugappa wassele'na (jangan berhenti berupaya, berusaha keras demi mendapatkan hasil yang diharapkan)”. Sebagaimana kehidupan pisang, nanti berhenti berpucuk setelah sudah berubah.

7. Kaluku lolo siagang golla eja/kelapa muda dan gula merah. Kelapa melambangkan kebermanfaatan yang sebanyak-banyaknya, sebagaimana diketahui bahwa tanaman kelapa, mulai akar, batang, daun, buah, kulit buah (sabut), dan airnya dapat dimanfaatkan oleh manusia. Sedangkan gula merah melambangkan sifat menebar kasih sayang, di mana gula senantiasa memberi rasa manis pada makanan. Dalam tradisi masyarakat Kelurahan Limbung Kecamatan Bajeng Kabupaten Gowa, menikmati kelapa terasa kurang lengkap tanpa adanya gula merah. Sepertinya, kelapa sudah identik dengan gula merah untuk mencapai rasa yang nikmat. Seperti itulah kehidupan rumah tangga, diharapkan suami istri senantiasa bersama, untuk saling melengkapi kekurangan dan menikmati pahit manisnya kehidupan duniawi.

Demikianlah rangkaian tata cara pelaksanaan tradisi akkorongtigi dan bahanbahan yang digunakan di dalamnya beserta pesan-pesan simbolik yang dapat dipetik. Penulis dapat menarik kesimpulan dasar bahwa sesungguhnya melalui pelaksanaan tradisi akkorongtigi para tokoh agama atau tokoh adat dahulu hendak menyampaikan 
muatan-muatan dakwah melalui pendekatan tradisi yang mengakar dalam masyarakat. Keunikan dari strategi dakwah model seperti ini adalah masyarakat tidak didakwahi secara verbal sebagaimana umumnya, namun melalui bahasa nonverbal, yang justru ketika benar-benar dimaknai oleh masyarakat, maka pesan-pesan dakwah yang terkandung di dalamnya sangat menyentuh dan mendalam maknanya. Hal yang sama pernah dipraktikkan oleh Rasulullah Muhammad saw., di mana Rasulullah saw. menggunakan simbol dahan kurma sebagai media dakwah (tafa'ul) untuk mendoakan keringanan siksa ahli kubur.

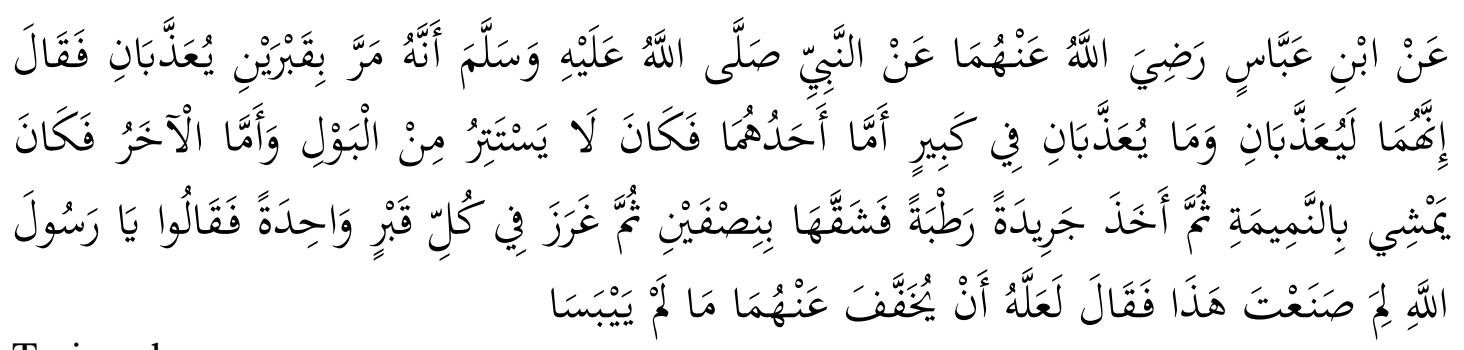

Terjemahnya:

Dari Ibnu 'Abbas ra. berkata, dari Nabi saw. bahwasanya beliau berjalan melewati dua kuburan yang penghuninya sedang disiksa, lalu beliau bersabda: "Keduanya sungguh sedang disiksa, dan tidaklah keduanya disiksa disebabkan karena berbuat dosa besar. Yang satu disiksa karena tidak bersuci setelah kencing sedang yang satunya lagi karena selalu mengadu domba". Kemudian beliau mengambil sebatang dahan kurma yang masih basah daunnya lalu membelahnya menjadi dua bagian kemudian menancapkannya pada masingmasing kuburan tersebut. Mereka bertanya: "Kenapa anda melakukan ini?". Nabi saw. menjawab: "Semoga diringankan (siksanya) selama batang pohon ini basah". ${ }^{11}$

Ditinjau dari segi bahasa, kata "dakwah" memang semakna dengan kata “doa”. Maka pengharapan atau doa-doa yang disimbolisasikan melalui prosesi dan bahan-bahan yang digunakan dalam tradisi akkorongtigi substansinya adalah aktivitas dakwah. Nilai-nilai dakwah pada tradisi seperti ini perlu diterangkan kepada masyarakat sehingga pelaksanaannya tidak sebatas seremonial dan "taklid buta" semata, namun benar-benar menghayati dan bisa mengaktualisasikannya, sehingga misi dakwah kultural melalui tradisi apa pun dan di mana pun bisa terlaksana dan efektif.

\footnotetext{
${ }^{11}$ HR. Bukhari No. 1273.
} 


\section{KESIMPULAN}

Akkorongtigi merupakan salah satu rangkaian tradisi pernikahan suku Makassar. Prosesnya diawali dengan appassili (mandi uap) di pagi hari, lalu pada malam hari dilaksanakan appatamma (khatam Alquran), dilanjutkan dengan acara inti yakni akkorongtigi dan ditutup dengan anynyori/annangra (pemberian sumbangan kepada keluarga calon mempelai). Setidaknya terdapat tujuh macam elemen atau bahan yang harus disiapkan pada prosesi akkorongtigi yang semuanya mengandung pesan-pesan dakwah simbolik kepada calon pengantin.

Melalui pelaksanaan tradisi akkorongtigi, para tokoh agama atau tokoh adat dahulu hendak menyampaikan muatan-muatan dakwah melalui pendekatan tradisi yang mengakar dalam masyarakat. Keunikan dari strategi dakwah model seperti ini adalah masyarakat tidak didakwahi secara verbal sebagaimana umumnya, namun melalui bahasa nonverbal yang luhur dan menyentuh bila mampu diinterpretasikan dengan arif muatan maknanya. 


\section{DAFTAR RUJUKAN}

Ahmad, Amrullah. "Dakwah Islam dan Perubahan Sosial" dalam Mulyadi, Dakwah Efektif. Makassar: Alauddin University Press, 2012.

AS, Enjang dan Aliyudin. Dasar-Dasar Ilmu Dakwah: Pendekatan Filosofis dan Praktis. Cet. I; Bandung; Widya Pandjadjaran, 2009.

Asmawarni. "Pesan Dakwah dalam Adat Akkorongtigi pada Masyarakat Kelurahan Limbung Kecamatan Bajeng Kabupaten Gowa (Suatu Tinjauan Dakwah Kultural)". Skripsi. Makassar: Fakultas Dakwah dan Komunikasi UIN Alauddin Makassar, 2015.

Aziz, Moh. Ali. Ilmu Dakwah. Cet. III; Jakarta: Kencana, 2012.

Basit, Abdul. FIlsafat Dakwah. Cet. I; Jakarta: Rajawali Pers, 2013.

Forum Silaturrahmi Keluarga Besar Alumni FIAD UNMUH Surabaya, "Dakwah Kultural", http://alumnifiad.youneed.us/t43-dakwah-kultural. (20 Maret 2015).

Ilaihi, Wahyu. Komunikasi Dakwah. Cet. I; Bandung; PT Remaja Rosdakarya, 2010.

Ilham, Muh. "Islam dan Budaya Lokal: Kearifan Lokal dalam Ungkapan Makassar dan Relevansinya dengan Pendidikan Islam”.Disertasi. Makassar: PPs UIN Alauddin, 2014.

Ismail, Ilyas. Filsafat Dakwah: Rekayasa Membangun Agama dan Peradaban Islam. Jakarta: Kencana, 2011.

Murodi. Sejarah Kebudayaan Islam. Semarang: PT Karya Toha Putra, [t.th.]

Nurnaga N, Andi. Tradisi Pernikahan Masyarakat Bugis Makassar. CV Telaga Nurnaga Zamzam. 2002.

Omar, Toha Yahya. "Ilmu Dakwah" dalam Mulyadi. Dakwah Efektif . Makassar: Alauddin University Press, 2012.

Pabittei, Sitti Aminah. Tradisi dan Upacara Perkawinan Daerah Sul-Sel. 1995.

Rosyidi. Dakwah Sufistik Kang Jalal. Jakarta: Paramidana, 2004.

Siradj, Said Aqil. Islam Kebangsaan Fiqh Demokratik Kaum Santri. Cet. I; Jakarta : Pustaka Ciganjur, 1999. 